\title{
PENGARUH PENERAPAN MODEL DISCOVERY LEARNING DISERTAI STRATEGI PEMBELAJARAN AKTIF TIPE TEKA-TEKI SILANG TERHADAP HASIL BELAJAR SISWA KELAS VII
}

\author{
Tri Wulan Puteri Angraini ${ }^{1)}$, Rahmi ${ }^{2)}$, Hafizah Delyana ${ }^{3)}$ \\ 1)2)3) Program Studi Pendidikan Matematika STKIP PGRI Sumatera Barat
} triwulanpa03@gmail.com, rahmi@gmail.com, hafizahd@gmail.com

\begin{abstract}
Background of The research by learning outcome student which still many below Complete Criterion Minimize (CCM). Other than that study process only predominated by group owning high ability. Purpose of this research are to know do there are influence model discovery learning accompanied active learning strategy of teka-teki silang type to learning outcome student of VII class SMP Negeri 9 Batanghari. Design of this research is pre-eksperimen research with research design of pre-test and post-test group. The population in research was all student of VII class SMP Negeri 9 Batanghari. Technique intake of sampel use Purposive Sampling, selected as class of sampel is VII B class. The research Instrument is pretest and post-test form essay. Technique analyse of pre-test and post-test the used $t$ test one side. Result of this result was learning outcome student after using model discovery learning accompanied active learning strategy of teka-teki silang type better of mean learning outcome of student before using model discovery learning accompanied active learning strategy of teka-teki silang type.
\end{abstract}

Keywords: Discovery Learning, Teka-teki Silang, Learning Outcome

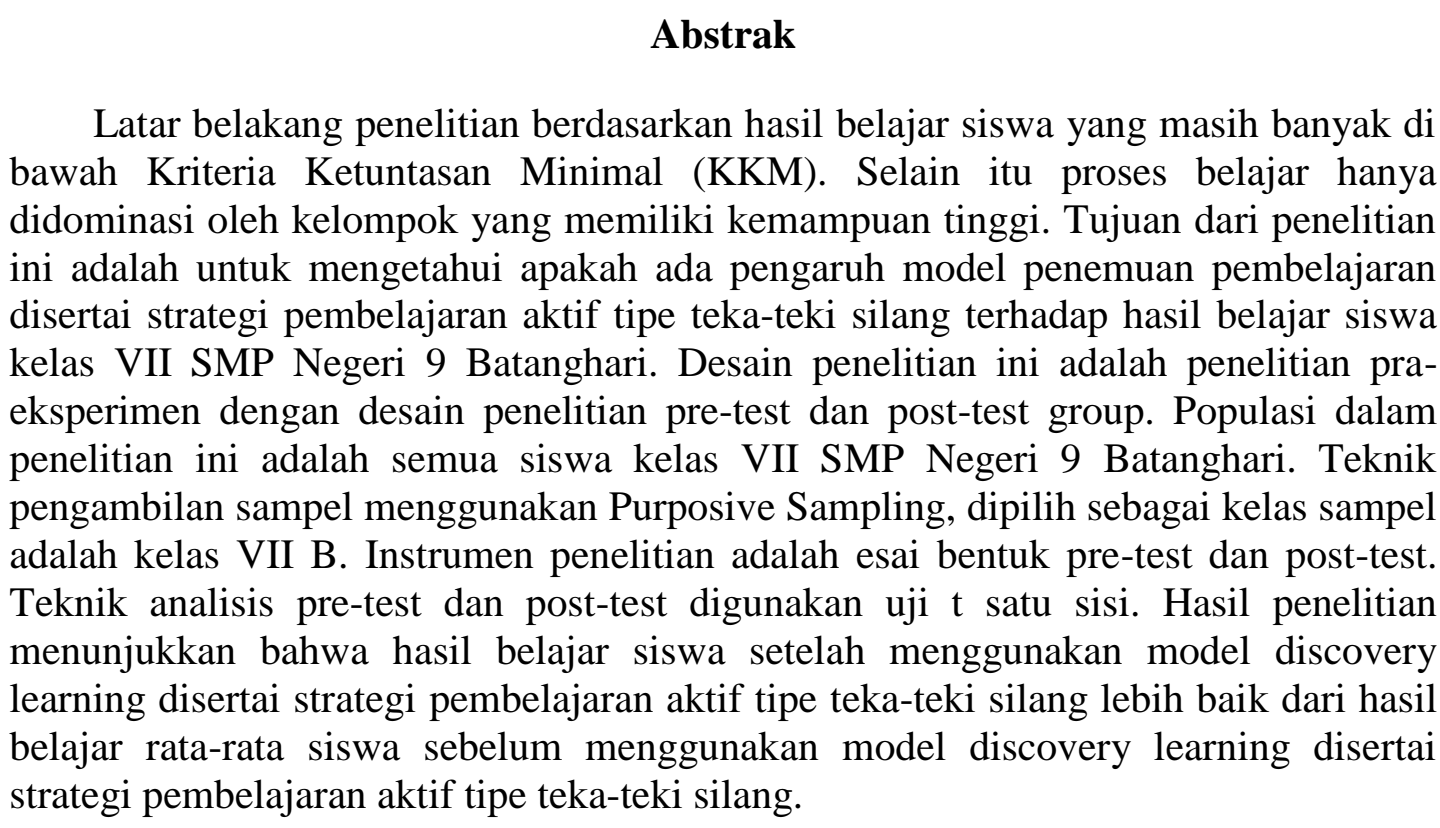

Latar belakang penelitian berdasarkan hasil belajar siswa yang masih banyak di bawah Kriteria Ketuntasan Minimal (KKM). Selain itu proses belajar hanya didominasi oleh kelompok yang memiliki kemampuan tinggi. Tujuan dari penelitian ini adalah untuk mengetahui apakah ada pengaruh model penemuan pembelajaran disertai strategi pembelajaran aktif tipe teka-teki silang terhadap hasil belajar siswa kelas VII SMP Negeri 9 Batanghari. Desain penelitian ini adalah penelitian praeksperimen dengan desain penelitian pre-test dan post-test group. Populasi dalam penelitian ini adalah semua siswa kelas VII SMP Negeri 9 Batanghari. Teknik pengambilan sampel menggunakan Purposive Sampling, dipilih sebagai kelas sampel adalah kelas VII B. Instrumen penelitian adalah esai bentuk pre-test dan post-test. Teknik analisis pre-test dan post-test digunakan uji t satu sisi. Hasil penelitian menunjukkan bahwa hasil belajar siswa setelah menggunakan model discovery learning disertai strategi pembelajaran aktif tipe teka-teki silang lebih baik dari hasil belajar rata-rata siswa sebelum menggunakan model discovery learning disertai strategi pembelajaran aktif tipe teka-teki silang.

Kata Kunci: Discovery Learning, Teka-teki Silang, Hasil Belajar 


\section{PENDAHULUAN}

Matematika merupakan salah satu mata pelajaran yang memiliki peranan penting, khususnya pada dunia pendidikan. Salah satu peranan matematika yaitu sebagai sarana berpikir ilmiah yang sangat mendukung untuk mengkaji IPTEK. Realisasi pentingnya pelajaran matematika diajarkan pada peserta didik, tercermin pada ditempatkannya matematika sebagai salah satu ilmu dasar untuk semua jenis dan jenjang pendidikan. Pentingnya pelajaran matematika, maka diperlukan perhatian yang lebih dalam, untuk meningkatkan kualitas pembelajaran matematika.

Kondisi yang ditemukan di sekolah, bahwa dalam pelaksanaan pembelajaran matematika hasil belajar yang diperoleh masih rendah salah satu penyebabnya adalah siswa belum paham dengan konsep matematisnya. Berdasarkan observasi yang dilakukan pada tanggal 16-23 November $2017 \mathrm{di}$ SMP Negeri 9 Batanghari, terlihat proses pembelajaran masih didominasi oleh guru, sementara keaktifan siswa dalam proses pembelajaran masih kurang. Pembelajaran hanya didominasi beberapa kelompok yang terdiri dari siswa yang tergolong memiliki kemampuan akademik tinggi. Sebagian besar siswa tidak memperhatikan penjelasan guru dan sibuk dengan aktifitas lain.

Berdasarkan wawancara dengan guru matematika kelas VII SMP Negeri 9 Batanghari diperoleh informasi bahwa hasil belajar siswa masih rendah. Pada saat proses pembelajaran guru membagi siswa dalam beberapa kelompok, namun siswa kurang bertanggung jawab dalam bekerja kelompok. Guru berupaya melakukan berbagai usaha diantaranya memberikan soal latihan dan pekerjaan rumah kepada siswa. Hal ini bertujuan agar siswa lebih paham dan terbiasa menyelesaikan soal-soal matematika. Siswa tidak mau bertanya terhadap materi yang belum dipahami, sedangkan ketika diberi soal tentang materi yang telah dipelajari hanya sebagian siswa yang menjawab dengan benar.

Hasil wawancara dengan beberapa orang siswa kelas VII SMP Negeri 9 Batanghari diperoleh keterangan bahwa matematika merupakan pelajaran yang susah dan sulit dipahami oleh siswa karena selalu dihubungkan dengan rumus. Siswa lebih suka bertanya kepada temannya daripada bertanya kepada guru. Siswa juga merasa bosan saat pembelajaran berlangsung, karena cara guru mengajar yang selalu sama. Sehingga siswa hanya diam, dan ada yang mengobrol dengan teman sebangkunya, serta ada pula yang tidurtiduran di dalam kelas.

$\begin{array}{crcr}\text { Salah } & \text { satu } & \text { solusi } & \text { dari } \\ \text { permasalahan } & \text { di } & \text { atas } & \text { adalah }\end{array}$ menerapkan model discovery learning. Menurut Persada (2016) model pembelajaran penemuan dapat mendorong siswa mengajukan dugaan awal, Menggunakan bahan dan permainan yang bervariasi, memberikan kesempatan pada siswa untuk memuaskan keingintahuan mereka, 
meskipun mereka mengajukan gagasan yang tidak berhubungan langsung dengan pembelajaran, dan menggunakan sejumlah contoh kontras untuk memperlihatkan perbedaan yang nyata dengan materi ajar topik-topik terkait.

Selain itu, Syah (2004) mengemukakan prosedur discovery learning adalah (1) Stimulasi, Pada tahap ini siswa dihadapkan pada sesuatu yang menimbulkan kebingungan dan dirangsang untuk melakukan kegiatan penyelidikan guna menjawab kebingungan tersebut. Kebingungan dalam diri siswa ini sejalan dengan adanya informasi yang belum tuntas disajikan guru; (2) Menyatakan Masalah, Pada tahap ini siswa diarahkan untuk mengidentifikasi sebanyak mungkin masalah yang relevan dengan bahan pelajaran, kemudian salah satunya dipilih dan dirumuskan dalam bentuk hipotesis; (3) Pengumpulan Data, Pada tahap ini siswa di tugaskan untuk melakukan kegiatan eksplorasi, pencarian, dan penelusuran dalam rangka mengumpulkan informasi sebanyakbanyaknya yang relevan untuk membuktikan benar hipotesis yang telah diajukannya. Kegiatan ini dapat dilakukan melalui aktifitas wawancara, kunjungan lapangan, atau kunjungan pustaka; (4) Pengolahan Data, Pada tahap ini siswa mengolah data dan informasi yang telah diperolehnya baik melalui wawancara, observasi, dan sebagainya, lalu ditafsirkan; (5) Pembuktian, Pada tahap ini siswa melakukan pemeriksaan secara cermat untuk membuktikan benar atau tidaknya hipotesis yang ditetapkan tadi dengan temuan alternatif, dihubungkan dengan hasil pengolahan data; (6) Menarik Kesimpulan, Pada tahap ini siswa menarik sebuah kesimpulan yang dapat dijadikan prinsip umum dan berlaku untuk semua kejadian atau masalah yang sama, dengan memperhatikan hasil verifikasi.

Pada penelitian ini model discovery learning disertai dengan strategi pembelajaran aktif tipe Tekateki Silang. Hal ini bertujuan agar materi yang telah dipelajari mampu diingat lebih lama dan hasil belajar matematika siswa dapat meningkat, karena guru menggunakan teka-teki silang sebagai latihan siswa.

Zaini (2008) mengemukakan langkah - langkah Teka-teki Silang sebagai berikut: Tulislah kata-kata kunci, terminologi atau nama-nama yang berhubungan dengan materi kuliah yang telah anda berikan, buatlah kisikisi yang dapat diisi dengan kata-kata yang telah dipilih (seperti dalam tekateki silang), hitamkan bagian yang tidak diperlukan, buat pertanyaan-pertanyaan yang jawabannya adalah kata-kata yang telah dibuat atau dapat juga hanya membuat pernyataan-pernyataan mengarah kepada kata-kata tersebut, bagikan teka-teki silang ini kepada peserta didik, bisa individu atau kelompok, batasi waktu mengerjakan, dan beri hadiah kepada kelompok atau individu yang mengerjakan paling cepat dan benar. 
Merujuk pada langkah-langkah strategi belajar aktif tipe teka-teki silang yang dikemukakan oleh Zaini (2008), dimodifikasi pada penulisan kata kunci mengenai materi pembelajaran. Materi pembelajaran yang digunakan di dalam pembuatan teka-teki silang adalah materi yang akan dipelajari hari itu. Teka-teki silang akan dilaksanakan sebagai latihan setelah pembelajaran discovery.

Penggunaan media teka-teki silang telah dilakukan oleh Zulfajri dan Amelia (2016), melalui discovery learning pada pada mata pelajaran kimia, hasilnya menunjukkan bahwa model Discovery Learning dengan media teka-teki silang sangat disukai oleh siswa dan layak digunakan dalam proses pembelajaran sehingga mampu meningkatkan hasil belajar siswa.

Berdasarkan penelusuran penggunaan media teka-teki silang sebelumnya belum pernah dilakukan, dalam pembelajaran matematika. Sehingga peneliti bermaksud untuk mengetahui pengaruh model Discovery Learning disertai strategi pembelajaran aktif tipe Teka- teki Silang terhadap hasil belajar matematika siswa kelas VII SMP Negeri 9 Batanghari.

\section{METODE PENELITIAN}

\section{Jenis Penelitian}

Desain Penelitian ini adalah penelitian pre-eksperimen dengan rancangan penelitian yaitu pre-test and post-test group.

\section{Subjek Penelitian}

Populasi penelitian ini adalah seluruh siswa kelas VII SMP Negeri 9 Batanghari, dengan sampel penelitian ditetapkan kelas VII B.

\section{Data, Instrumen dan Teknik Pengumpulan data}

Instrumen penelitian adalah pretest dan post-test berbentuk esai dengan jumlah soal sebanyak 7 buah. Soal pretest dan post-tes diujicobakan di SMP Negeri 9 Batanghari. Hasil analisis butir soal, diketahui kriteria reliabilitas tes yang diukur berdasarkan Arikunto (2010), hasil perhitungan diperoleh $\mathrm{r}_{11}=0,83$, artinya soal tes akhir reliabel.

\section{Teknik Analisis Data}

Teknik analisis data dalam pengujian hipotesis menggunakan uji $t$ test dengan merujuk pada Sudjana (2005).

Hipotesis penelitian ini adalah terdapat pengaruh model Discovery Learning disertai strategi pembelajaran aktif tipe teka-teki silang terhadap hasil belajar matematika siswa di kelas VII SMP Negeri 9 Batanghari. Sebelum melakukan uji hopotesis terlebih dahulu dilakukan uji normalitas dan uji homogenitas variansi terhadap kedua kelas sampel.

\section{HASIL DAN PEMBAHASAN}

Berdasarkan penelitian yang dilakukan pada tanggal 30 April- 15 Mei 2018 diperoleh data tentang hasil 
belajar matematika siswa setelah dilaksanakan pre-test dan post-test.

Hasil perhitungan dapat dilihat pada Tabel 1.

Tabel 1. Hasil Perhitungan Pre-test dan Post-test Siswa Kelas Eksperimen

\begin{tabular}{|c|c|c|c|c|c|}
\hline Kelas & $\mathbf{n}$ & $\overline{\boldsymbol{x}}$ & $\mathbf{S}$ & $\boldsymbol{x}_{\boldsymbol{m a x}}$ & $\boldsymbol{x}_{\boldsymbol{m i n}}$ \\
\hline Pre-test & 25 & 23,88 & 10,41 & 54 & 9 \\
\hline Post-test & 25 & 66,96 & 17,81 & 100 & 37 \\
\hline
\end{tabular}

Pada Tabel 1 dapat dilihat bahwa pada pre-test nilai tertinggi yang diperoleh siswa adalah 54 dan terendah adalah 9. Pada post-test nilai tertinggi adalah 100 dan terendah adalah 37. Simpangan baku pre-test diperoleh 10,41 dan simpangan baku post-test diperoleh 17,81. Hal ini menunjukkan bahwa nilai post-test lebih beragam dari pada nilai pre-test, sehingga menyebabkan nilai siswa tersebar terlalu jauh dari nilai rata-rata kelas. Pre-test dan post-test diikuti oleh 25 orang siswa dengan perhitungan ratarata pre-test siswa adalah 23,88 dan rata-rata post-test siswa adalah 66,96 , sehingga diperoleh selisih perhitungan rata-rata adalah 43,08. Berdasarkan hasil pre-test dan post-test tersebut, dapat dikatakan bahwa hasil belajar siswa pada saat post-test lebih tinggi dari hasil pre-test.

Hasil analisis data untuk uji hipotesis menggunakan uji t. Kriteria pengujian yaitu $\mathrm{H}_{0}$ ditolak jika : $t>t_{\alpha}$. Hasil perhitungan diperoleh nilai $\mathrm{t}=$ 10,51 dengan $\mathrm{N}=25$ dan $\alpha=0,05$, sedangkan $t_{\alpha}=1,71$. Karena nilai $t>t_{\alpha}$ maka $\mathrm{H}_{0}$ ditolak. Sehingga dapat disimpulkan bahwa hasil belajar matematika siswa setelah melaksanakan model pembelajaran discovery learning disertai strategi pembelajaran aktif tipe teka-teki silang lebih baik dari pada hasil belajar matematika siswa sebelum melaksanakan model pembelajaran discovery learning disertai strategi pembelajaran aktif tipe teka-teki silang. Hal ini sesuai dengan penelitian Supriyanto (2014) yang menunjukkan bahwa pembelajaran discovery learning dapat meningkatkan hasil dan keaktifan belajar siswa.

Pembelajaran di kelas eksperimen menggunakan model pembelajaran discovery learning disertai strategi pembelajaran aktif tipe teka-teki silang. Pelaksanaan pembelajaran dimulai dengan salam dan berdoa, mengecek kehadiran siswa, menyampaikan tujuan dan cakupan materi pelajaran yang akan dicapai oleh siswa, memberikan motivasi dan apersepsi untuk mengikuti pembelajaran. Kemudian guru meminta siswa untuk membaca buku paket dan mengajukan pertanyaan mengenai materi yang dipelajari, setelah itu guru memberikan gambaran awal mengenai materi pembelajaran dengan mengaitkan materi dengan kehidupan nyata yang ada di sekitar, serta meminta siswa untuk mengidentifikasi masalah yang telah diberikan dan merumuskannya dalam bentuk hipotesis. Setelah dirumuskan pertanyaan-pertanyaan siswa, guru membagi siswa ke dalam beberapa 
kelompok secara heterogen masingmasing kelompok terdiri dari 4-5 orang siswa.

Guru memberikan lembar kerja kepada masing-masing kelompok, dan kelompok diberikan waktu untuk berdiskusi dalam menyelesaikan lembar kerja. Kegiatan yang dilakukan oleh siswa di dalam kelompok dimulai dengan mengumpulkan data-data yang diperlukan, dari buku hingga melakukan uji coba sendiri di dalam kelompok. Kegiatan yang dilaksanakan kelompok bertujuan agar memperoleh informasi atau data yang dibutuhkan untuk diolah, sehingga kelompok dapat menyelesaikan lembar kerja siswa yang telah diberikan. Penyelesaian lembar kerja siswa yaitu dengan melengkapi titik-titik yang ada pada tabel dengan data yang telah diperoleh.

Setelah siswa mendapatkan informasi atau data dari lembar kerja yang sudah dikerjakan, kemudian siswa secara berkelompok mengolah informasi yang sudah didapatkan dengan menuliskan kembali apa yang mereka temukan dari kegiatan sebelumnya. Kegiatan ini dilakukan untuk melihat pemahaman siswa terkait informasi dan data yang telah mereka peroleh, sehingga siswa mampu menemukan sendiri suatu konsep dari materi pembelajaran. Selanjutnya guru memastikan kepada kelompok, agar setiap anggota kelompok memahami tentang konsep yang telah ditemukan. Setelah kegiatan diskusi, guru memanggil salah satu kelompok secara acak dengan loting, bagi kelompok yang terpanggil maju ke depan kelas untuk membacakan hasil penemuan dan hasil diskusinya.

Selanjutnya, setelah kelompok menampilkan hasil penemuan dan diskusi kelompoknya, guru memberikan soal latihan kepada siswa dalam bentuk lembar teka-teki silang matematika. Lembar teka-teki silang matematika yang diberikan oleh guru kepada siswa diselesaikan secara individu. Pada penyelesaian teka-teki silang matematika, untuk siswa yang mampu mengumpulkan teka-teki silang tercepat dan semua jawaban benar maka siswa akan diberi nilai tambahan. Setelah siswa menyelesaikan latihan teka-teki silang matematika, guru mengajak siswa secara bersama untuk menyimpulkan hasil dari pembelajaran yang telah dilaksanakan, serta guru memberikan pekerjaan rumah sebagai tugas akhir dalam pembelajaran hari itu kepada siswa.

Berikut salah satu hasil jawaban siswa untuk soal pre-test dan post-test. 


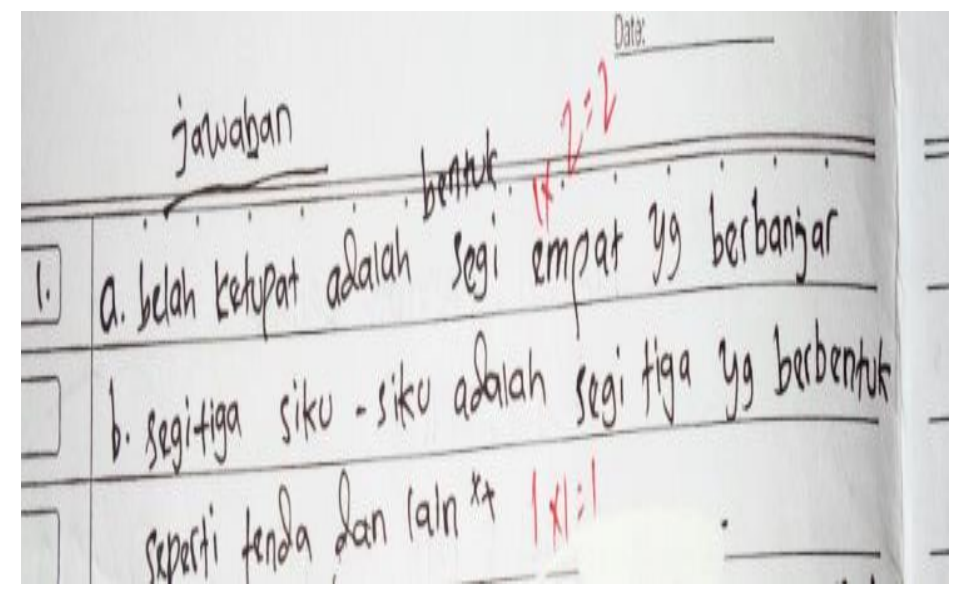

Gambar 1. Lembar Jawaban Pre-test Siswa

Berdasarkan Gambar 1 untuk soal pre-test terlihat bahwa siswa belum mampu menjelaskan pengertian dari masing-masing segiempat dan segitiga berdasarkan bentuk segiempat dan segitiga. Jawaban yang dimaksud yaitu belah ketupat adalah segiempat yang semua sisi-sisinya sama panjang dan sudut-sudut yang berhadapan sama besar dan segitiga siku-siku adalah segitiga yang memiliki satu sudut yang tepat sebesar $90^{\circ}$.

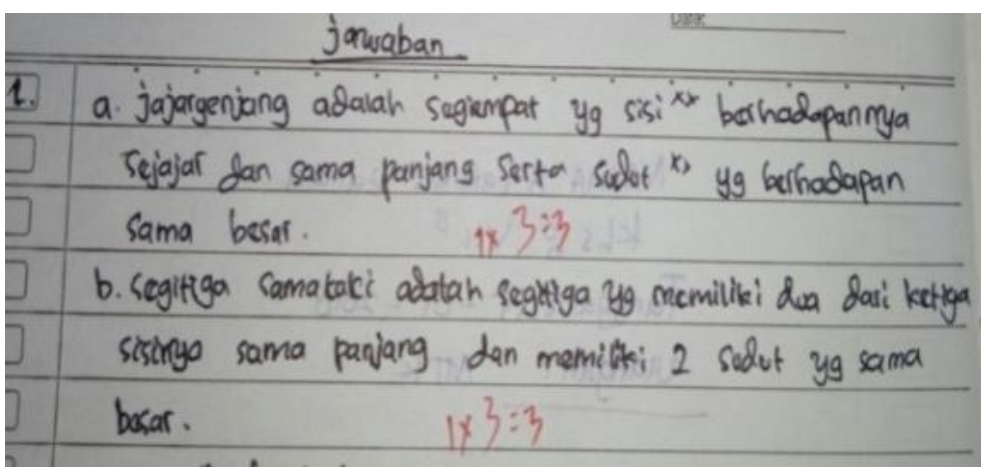

Gambar 2. Lembar Jawaban Post-test Siswa

Berdasarkan Gambar 2, sudah dapat terlihat perubahan dari cara siswa menjawab antara soal pre-test dan posttest. Pada Gambar 2 terlihat bahwa jawaban siswa sudah pada skala 3 atau sesuai dengan apa yang diminta soal, dimana siswa sudah mampu menjawab dengan benar apa yang dimaksud dengan jajargenjang dan segitiga samakaki. Ini menandakan bahwa siswa sudah mulai mampu menjelaskan pengertian dari masing-masing segiempat dan segitiga.
Berdasarkan pembahasan hasil kerja siswa dan hasil tes akhir, terlihat bahwa siswa sudah mampu dalam menjawab permasalahan yang diberikan serta mampu menemukan konsep dari materi yang dipelajari. Selain itu, berdasarkan analalisis data diperoleh bahwa skor nilai rata-rata post-test siswa lebih tinggi daripada skor nilai rata-rata pre-test siswa. Selanjutnya berdasarkan uji hipotesis dikatakan bahwa kemampuan matematis siswa setelah menggunakan Model Discovery 
Learning Disertai Strategi Pembelajaran Aktif Tipe Teka-teki Silang lebih baik daripada sebelum menggunakan model tersebut.

Penelitian yang telah dilakukan dengan menggunakan Model Discovery Learning Disertai Strategi Pembelajaran Aktif Tipe Teka-teki Silang membuat siswa mampu menemukan sendiri suatu konsep melalui eksperimen atau uji coba yang dilakukan secara individu maupun berkelompok. Setelah siswa mampu menemukan sendiri suatu konsep, maka siswa diberikan latihan berupa teka-teki silang untuk memperdalam ingatan siswa terhadap konsep yang telah diperoleh.

Sejalan dengan apa yang sudah dilaksanakan, bahwa dengan menggunakan model discovery learning disertai strategi pembelajaran aktif tipe teka-teka silang di dalam proses pembelajaran, dapat mendorong siswa untuk melakukan sendiri penemuan terhadap konsep dari topik yang dipelajari. Sehingga pembelajaran yang dilakukan lebih bermakna dan membuat siswa menjadi lebih mengerti dengan materi pelajaran yang dipelajari. Hal ini sejalan dengan yang dilaksanakan oleh Risanti (2017), bahwa siswa mampu menemukan suatu konsep yang dibimbing oleh guru melalui eksperimen atau uji coba sendiri di dalam kelompok. Selain itu juga dapat meningkatkan rasa tanggung jawab siswa terhadap kelompok dan diri sendiri. Selain itu juga sejalan dengan Sari (2017), bahwa siswa antusias mengikuti pembelajaran dengan adanya pengisian teka-teki silang sebagai evaluasi di akhir pembebelajaran sebagai pengulangan materi. Hal ini menunjukkan bahwa adanya peningkatan disiplin, tertib, komunikatif, rasa ingin tahu, tanggung jawab dan kreatifitas siswa. Selain itu penggunaan media teka teki silang dapat meningkatkan motivasi belajar siswa sehingga berpengaruh terhadap hasil belajar siswa juga. Davis et al (2009) menyimpulkan bahwa permainan yang digunakan sebagai media pembelajaran secara langsung dapat merangsang minat siswa dan dapat menjadi teknik motivasi yang baik.

\section{SIMPULAN DAN SARAN}

\section{Simpulan}

Berdasarkan hasil penelitian yang diperoleh setelah melakukan analisis dan pembahasan terhadap masalah yang telah dikemukakan dapat diambil kesimpulan bahwa terdapat pengaruh penerapan model discovery learning disertai strategi pembelajaran aktif tipe teka-teki silang terhadap hasil belajar siswa kelas VII SMP Negeri 9 Batanghari.

\section{Saran}

Berdasarkan kesimpulan hasil penelitian, penerapan discovery learning disertai dengan penggunaan media tekateki silang dapat dijadikan sebagai alternatif dalam pembelajaran matematika untuk meningkatkan hasil belajar siswa. 
DAFTAR PUSTAKA

Davis, T., M., Shepherd, B \& Zwiefelhofer, T. (2009). Reviewing for Exam: Do Crossword Puzzles Help in the success of Student Learning?. The Journal of Effevtive Teaching. Vol. 9(3), 4-10.

Depdiknas. (2001). Penyusunan Butir Soal dan Instrumen Penilaian. Jakarta: Dikdasmen.

Persada, A., R. (2016). Pengaruh Model Pembelajaran Penemuan (Discovery Learning) Terhadap Kemampuan Koneksi Matematika Siswa (Studi Eksperimen Terhadap Siswa Kelas VII SMPN 2 Sindangagung Kabupaten Kuningan Pada Pokok Bahasan Segiempat. Eduma, Vol. 5 No. 2, Desember 2016.

Risanti, I. (2017). Penerapan Model Pembelajaran Discovery Learning Disertai Numbered Heads Terhadap Hasil Belajar Matematika Siswa Kelas VIII SMP Negeri 12 Padang. STKIP PGRI SUMBAR.

Sari, N., P. (2017). Pengaruh penerapan Pembelajaran Kooperatif Disertai Teka-Teki Silang Terhadap Pemahaman Konsep Matematis Siswa Kelas XI IPS SMAN 4 Sijunjung Tahun pelajaran 2016/2017. STKIP PGRI SUMBAR.

Setiawan, Veri. Dkk. 2018. Penerapan

Model Pembelajaran Discovery Learning Untuk Meningkatkan Minat Dan Prestasi Belajar. Prosiding Seminar

Nasional Pendidikan Matematika Etnomatnesia Tahun 2018
Sudjana. (2005). Metoda Statistika. Bandung: Tarsito.

Supriyanto, B. (2014). Penerapan discovery learning untuk meningkatkan hasil belajar siswa mata pelajaran matematika pokok bahasan keliling dan luas lingkaran. Jurnal: Pancaran, 3, 165-174.

Syah. (2004). Psikologi Pendidikan dengan Pendekatan Baru. Bandung: PT Remaja Rosdakarya

Zaini, H. (2008). Strategi Pembelajaran Aktif. Yogyakarta: Pustaka Insan Madani.

Zulfajri, M \& Amelia, R. (2016). Pengaruh model discovery learning dengan media teka-teki silang terhadap peningkatan hasil belajar siswa pada materi sistem koloid. Jurnal Edukasi Kimia. Vol. 1(1), 12-18. 